\title{
Effect of aqueous extract of Acacia nilotica ssp adansonii on milk production and prolactin release in the rat
}

\author{
Zourata Lompo-Ouedraogo ${ }^{1,2}$, Daan van der Heide ${ }^{1}$, \\ Eline $M$ van der Beek ${ }^{1}$, Hans J M Swarts ${ }^{1}$, John A M Mattheij ${ }^{1}$ \\ and Laya Sawadogo ${ }^{2}$ \\ ${ }^{1}$ Human and Animal Physiology Group, Department of Animal Sciences, Wageningen University, Wageningen, The Netherlands \\ ${ }^{2}$ Unité de Formation et de Recherche en Sciences de la Vie et de la Terre, Université de Ouagadougou, Burkina Faso \\ (Requests for offprints should be addressed to D van der Heide; Email: daan.vanderheide@wur.nl)
}

\begin{abstract}
In view of the traditional belief that Acacia nilotica ssp adansonii (AN) can stimulate milk production in lactating women, experiments were performed to determine the effect of an aqueous extract of AN on milk production in rats. Female rats that received oral doses of aqueous extract of this plant during their first lactation produced about $59 \%$ more milk than controls $(P<0 \cdot 01)$. Pup weight gain was also significantly higher than that in the control group. A lower dose, comparable to that used by women to improve their milk yield, led to about $33 \%$ more milk with the same growth rate for pups as that in the high-dose
\end{abstract}

group. The extract of AN was found to stimulate the synthesis and release of prolactin (PRL) significantly $(P<0 \cdot 05)$. In addition, the mammary glands of oestrogenprimed rats treated with the extract showed clear lobuloalveolar development with milk secretion. This study demonstrates that the aqueous extract of AN can stimulate milk production and PRL release in the female rat and could consequently have the properties claimed for lactating women.

Journal of Endocrinology (2004) 182, 257-266

\section{Introduction}

African women with milk production deficiencies traditionally use plant extracts to induce milk production or to increase milk yield. With limited access to modern milk replacers, breastfeeding is essential for the newborn's survival. Most plant extracts are generally used in the form of decoction or maceration. The floristic and ethnobotanic aspects of lactogenic plants have been studied extensively (Bognounou et al. 1974, Adjanohoun et al. 1979a,b, Nacoulma-Ouedraogo 1996); however, little is known about their biological activities. On the other hand, the positive effect of Asparagus racemosus extract on milk production in buffaloes has been reported (Patel \& Kanitkar 1969). Some plants have been identified as lactogenic because of a capacity to stimulate the synthesis of lactogenic hormones (prolactin (PRL), growth hormone, cortisol) and/or $\beta$-endorphin and $\beta$-casein accumulation in the mammary gland in vivo and in vitro (Sawadogo 1987, Sawadogo \& Houdebine 1988, Sawadogo et al.1988a,b). Indeed, PRL is known to play a key role in mammogenesis and lactogenesis (Djiane et al. 1982, Hennighausen et al. 1997, Brisken et al. 1999, Horseman 1999, Llovera et al. 2000) in all species, including the rat. However, for PRL to exert its

mitotic effect, the tissue must be exposed to oestrogen (Silberstein et al. 1994). In rodents, the initiation of lactation has the obligate requirement of PRL (Knight et al. 1986, Madon et al. 1986). After parturition, PRL induces lactation by direct stimulation of the synthesis of milk proteins in the epithelial cells and indirect stimulation of the proliferation of secretory cells. However, growth hormone $(\mathrm{GH})$ is needed to support milk production when PRL is reduced (Flint et al. 1992). A few plants have been described which stimulate PRL release (Sawadogo 1987), milk production (Patel \& Kanitkar 1969) or mammary gland development (Sabnis et al. 1969). However, an exact relationship between these effects for a given plant has not yet been established.

In Burkina Faso, Acacia nilotica ssp adansonii (AN) is one of the plants widely used in folk medicine, in particular during lactation.

A. nilotica species have been reported to have antihyperglycaemic (Akhtar \& Khan 1985), antimicrobial (Sotohy et al. 1997), antiplasmodial (El-Tahir et al. 1999), anti-inflammatory, analgesic and antipyretic (Dafallah \& al-Mustapha 1996) properties. The methanol extract of the pods of $A$. nilotica ssp shows antihypertensive activities (Gilani et al. 1999), and the aqueous extract of the seeds exhibits spasmogenic and vasoconstrictor actions 
(Amos et al. 1999). A. nilotica subspecies are traditionally used in Pakistan for the treatment of diarrhoea, and Shah et al. (1997) have recently found antiplatelet aggregatory activities. Methanol (bark and pods) and aqueous (pods) extract of $A$. nilotica shows considerable inhibitory effects against HIV-1 protease (Hussein et al. 1999) and hepatitis C virus protease (Hussein et al. 2000). However, despite its widespread use in folk medicine for the treatment of many diseases, little is known about its biological effects in induction and stimulation of lactation.

In view of the claim that $\mathrm{AN}$ extract is frequently used traditionally to improve lactation, experiments were performed to determine whether AN extract can stimulate milk production, PRL release and mammary gland development in the rat.

\section{Materials and Methods}

\section{Preparation of the plant extract}

Traditionally, a nursing woman ( $\pm 65 \mathrm{~kg}$ in body weight) drinks the extract of about $100 \mathrm{~g}$ dry AN leaves per day. For our experiments, AN fresh leaves were air-dried in the shade and pulverised, and then boiled in water for $15 \mathrm{~min}$ $(1: 4 \mathrm{w} / \mathrm{w})$. After centrifugation, the supernatant was freeze-dried and the dry material was weighed. The yield in crude extract was about 18\% of dry leaves. All doses used in the experiments were based on this estimation.

For each experiment, a sample of the freeze-dried extract was dissolved in $0.9 \% \mathrm{NaCl}$, centrifuged at $3000 \mathrm{~g}$ for $10 \mathrm{~min}$ and stored at $4{ }^{\circ} \mathrm{C}$.

\section{Animals}

For all experiments, mature Wistar rats were purchased from Charles River (Lyon, France), and maintained on a 12-h light-dark cycle (lights on from 0600 to $1800 \mathrm{~h}$ ). They were housed individually in standard plastic cages with wood chips on the floor and were allowed access to food and water ad libitum. All experiments were seen and approved by the animal experimental committee of the University of Wageningen and the University of Ouagadougou.

\section{Experimental protocols}

\section{Experiment I: effect of oral treatment with AN extract on milk production}

Experiment $A$ Eighteen lactating dams weighing 225$250 \mathrm{~g}$ at the beginning of lactation and suckling eight to nine pups were used for this experiment. Females were divided into three experimental groups and received $2 \mathrm{ml}$ of $0.9 \% \mathrm{NaCl}(n=6)$, and $280 \mathrm{mg}(n=6)$ and $560 \mathrm{mg}$ of plant extract/ $\mathrm{kg}$ body weight per $2 \mathrm{ml} 0.9 \% \mathrm{NaCl}(n=6)$ respectively. All animals were treated daily, starting on the evening of day 2 of lactation. The extract was administered orally with a gavage syringe each day at $1800 \mathrm{~h}$. Milk production was estimated $18 \mathrm{~h}$ after gavage. Milk production was measured from day 3 to day 15 of lactation. Milk yield and body weight of dams, and weight gain of pups were measured each day with an electronic balance (Sartorius Basic Plus) accurate to $0 \cdot 01 \mathrm{~g}$.

Every day during the study period, the pups were weighed at $0700 \mathrm{~h}$ (w1) and subsequently isolated from their mother for 4 h (Sampson \& Jansen 1984). At 1100 h, the pups were weighed (w2), returned to their mother and allowed to feed for $1 \mathrm{~h}$. At $1200 \mathrm{~h}$, they were weighed (w3). Milk yield $18 \mathrm{~h}$ after the gavage was estimated as w3 - w2. Daily milk yield was corrected for weight loss due to metabolic processes in the pup (respiration, urination and defecation) during suckling. The value used was (w2 $-w 1) / 4$. This value was then multiplied by the number of suckling hours per day and added to the daily suckling gain (Sampson \& Jansen 1984). Daily weight gain of pups was calculated from the pup weight at w2.

Experiment B Fifteen lactating dams weighing 225-250 g at the beginning of lactation and suckling eight to nine pups were divided into two experimental groups and received $2 \mathrm{ml} 0.9 \% \mathrm{NaCl}(n=7)$ and $280 \mathrm{mg}$ of plant extract/ $\mathrm{kg}$ body weight per $2 \mathrm{ml} 0.9 \% \mathrm{NaCl}(n=8)$, respectively.

All animals were treated daily, starting on the evening of day 2 of lactation. The extract was administered orally with a gavage syringe each day at $1800 \mathrm{~h}$. Milk production was estimated at 18 and $23 \mathrm{~h}$ after gavage. For the measurement of milk yield $18 \mathrm{~h}$ after gavage, the same procedure as described above for experiment A was followed. For measurement of milk yield $23 \mathrm{~h}$ after gavage, the pups were subsequently isolated between 1200 and $1600 \mathrm{~h}$. After weighing at $1600 \mathrm{~h} \mathrm{(w4),} \mathrm{they} \mathrm{were}$ reunited with their mother for $1 \mathrm{~h}$ of feeding and, finally, they were weighed (w5). They were subsequently left with their mother during the night. Milk yield $23 \mathrm{~h}$ after gavage was estimated as w5 - w4. Daily milk yield was corrected for weight loss due to metabolic processes in the pup (respiration, urination and defecation) during suckling. The value used for correction for weight loss was $[(\mathrm{w} 2-\mathrm{w} 1)+(\mathrm{w} 4-\mathrm{w} 3)] / 8$. This value was then multiplied by the number of suckling hours per day and added to the daily suckling gain (Sampson \& Jansen 1984). Daily weight gain of pups was again calculated from the pup weight at w2.

Experiment II: effect of i.v. injection of AN extract on plasma and pituitary PRL concentration Eighteen cycling virgin rats aged 90 days and weighing 200-250 g were cannulated in the jugular vein by the method described by Van Dongen (1990). A week after cannulation, the animals were divided into three groups and 
received either $0.2 \mathrm{ml} 0.9 \% \mathrm{NaCl}$, or 45 or $110 \mathrm{mg}$ plant extract $/ \mathrm{kg}$ body weight per $0.2 \mathrm{ml} \quad 0.9 \% \mathrm{NaCl}$. All doses were given as a single injection each day via the intravenous cannula during a period of 6 days.

Animals were adjusted to blood-sampling procedures 2 days before the start of the experiment. On day 1 (at dioestrous) and day 3 (at oestrus) of the treatment, two plasma samples were taken before and five samples after the injection, at 20-min intervals. The blood samples were centrifuged and plasma was stored at $-20^{\circ} \mathrm{C}$ until radioimmunoassay (RIA) for PRL content. On day 7 of the experiment, the animals were killed by decapitation under ether anaesthesia. Pituitaries were collected for PRL extraction. Extraction occurred in a Potter tube at $0{ }^{\circ} \mathrm{C}$ with PBS pH 7.4, 0.03 M; $10 \mu \mathrm{l}$ of the homogenate were diluted with phosphate buffer plus 1\% BSA and stored at $-20{ }^{\circ} \mathrm{C}$.

Plasma and pituitary PRL levels were measured using rat reagents distributed by the NIDDK (NIH, Bethesda, MD, USA). PRL values were expressed in terms of the reference standards RP-3. The intra-assay variation are 7.92\% and $9 \cdot 95 \%$ for plasma PRL and pituitary PRL respectively.

Experiment III: effect of i.m. injection of AN extract on mammary gland tissue The animals used in this experiment were first-generation descendants of the rats purchased from IFFA-CREDO. Thirty-six virgin female rats aged 60-70 days were divided into two groups. The first group first received a subcutaneous injection of oestradiol (E2) in a dose of $10 \mu \mathrm{g} / 0 \cdot 1 \mathrm{ml}$ sesame oil twice daily for 2 days. Subsequently they were divided into three subgroups and received an i.m. injection of either $0.9 \%$ $\mathrm{NaCl}$, or 200 or $400 \mathrm{mg}$ plant extract/ $\mathrm{kg}$ body weight twice daily for 5 days. The second group first received an injection of $0.9 \% \mathrm{NaCl}$ and was then divided into three subgroups receiving the same injections as the first group. On day 6, all animals were anaesthetised with ether and killed by decapitation. Pituitaries were collected for PRL extraction, as previously described. The two inguinal mammary glands were removed, immediately fixed in alcoholic Bouin and then embedded in paraffin wax after dehydration in a graded series of ethanol and xylene. Paraffin sections $(5 \mu \mathrm{m})$ of the mammary glands were sliced and stained with Harris' haematoxylin and eosin. Mammary gland structures were identified by the criteria of Russo and Russo $(1978,1996)$ and Masso-Welch et al. (2000), using a Zeiss microscope coupled to an image analysis system.

\section{Experiment IV: effect of the treatment with AN} extract after bromocriptine injection Twenty-four female rats at 90 days old were divided into four groups. Two groups were treated orally with $2 \mathrm{ml} \mathrm{NaCl} 0.9 \%$ $(n=6)$ and $550 \mathrm{mg}$ plant extract $/ \mathrm{kg}$ body weight per $2 \mathrm{ml}$ $\mathrm{NaCl} 0 \cdot 9 \%(n=6)$ twice daily during 5 days respectively.
The remaining two groups were treated subcutaneously with bromocriptine (CB154) at a dose of $4.5 \mathrm{mg} / \mathrm{kg}$ body weight per $0 \cdot 25 \mathrm{ml}$ ethanol $70 \%$ twice daily during 2 days. Then they were treated orally by gavage with $2 \mathrm{ml} \mathrm{NaCl}$ $0.9 \%(n=6)$ or $550 \mathrm{mg}$ plant extract/kg body weight per $2 \mathrm{ml} \mathrm{NaCl} 0.9 \%(n=6)$ twice daily during 3 days. On day 6 , all the animals were anaesthetised with ether and killed by decapitation. Pituitaries were collected for PRL extraction and determined as described above.

\section{Statistical analysis}

Data were analysed by Student's $t$-test or one-way ANOVA followed by the Bonferroni or Scheffe test or least square difference (LSD), using the statistical package SPSS (version 7.5 for Windows). Data that were not normally distributed (plasma PRL concentrations in experiment II) were analysed using the non-parametric Kruskal-Wallis test. $P<0 \cdot 05$ was considered significant.

\section{Results}

\section{Milk production}

Milk production of both groups receiving 280 and $560 \mathrm{mg}$ of plant extract was higher than that of the control group, as illustrated in Fig. 1A (experiment A). Milk yield increased from $1.38 \pm 0.16,1.44 \pm 0.15$ and $1.52 \pm$ $0 \cdot 05 \mathrm{~g} /$ pup per day to about $3 \cdot 07 \pm 0 \cdot 29,4 \cdot 46 \pm 0.06$ and $5 \cdot 27 \pm 0.15 \mathrm{~g}$ /pup per day for the controls, and those receiving 280 and $560 \mathrm{mg}$ respectively. The differences observed were significant from day 2 until the end of treatment, in particular for the $560 \mathrm{mg}$ dose group (ANOVA followed by Bonferroni, $P<0 \cdot 01$ ). The mean milk yield was $2 \cdot 12 \pm 0 \cdot 17,2 \cdot 83 \pm 0 \cdot 23$ and $3 \cdot 36 \pm$ $0.32 \mathrm{~g} /$ pup per day over the experimental period respectively (Student's $t$-test with Bonferroni correction at least $P<0 \cdot 05)$ (Fig. 1B).

Milk production data 18 and $23 \mathrm{~h}$ after gavage indicated that milk production was significantly increased in all groups receiving the extract, at both time points (ANOVA followed by the Scheffe test, $P<0 \cdot 05$ ) (Fig. 2). The mean milk yield for the control group was $0.37 \pm 0.02$ and $0.38 \pm 0.03 \mathrm{~g} /$ pup at 5,18 and $23 \mathrm{~h}$ after gavage with saline respectively. For the group receiving the extract, the mean milk yield was $0.51 \pm 0.02$ and $0.57 \pm 0.03 \mathrm{~g} /$ pup at 5,18 and $23 \mathrm{~h}$ after treatment respectively.

\section{Body weight}

All pups gained weight during the study period (Fig. 3A) and the rate of weight gain for the treated groups was significantly higher than that for the controls. Body weight increased from $7 \cdot 83 \pm 0 \cdot 39$ to $17 \cdot 65 \pm 1 \cdot 54 \mathrm{~g} /$ pup per day for the controls, from $8 \cdot 17 \pm 0.66$ to $22 \cdot 94 \pm 0.57 \mathrm{~g} / \mathrm{pup}$ per day for those receiving $280 \mathrm{mg}$, and from $8.72 \pm 0.39$ 

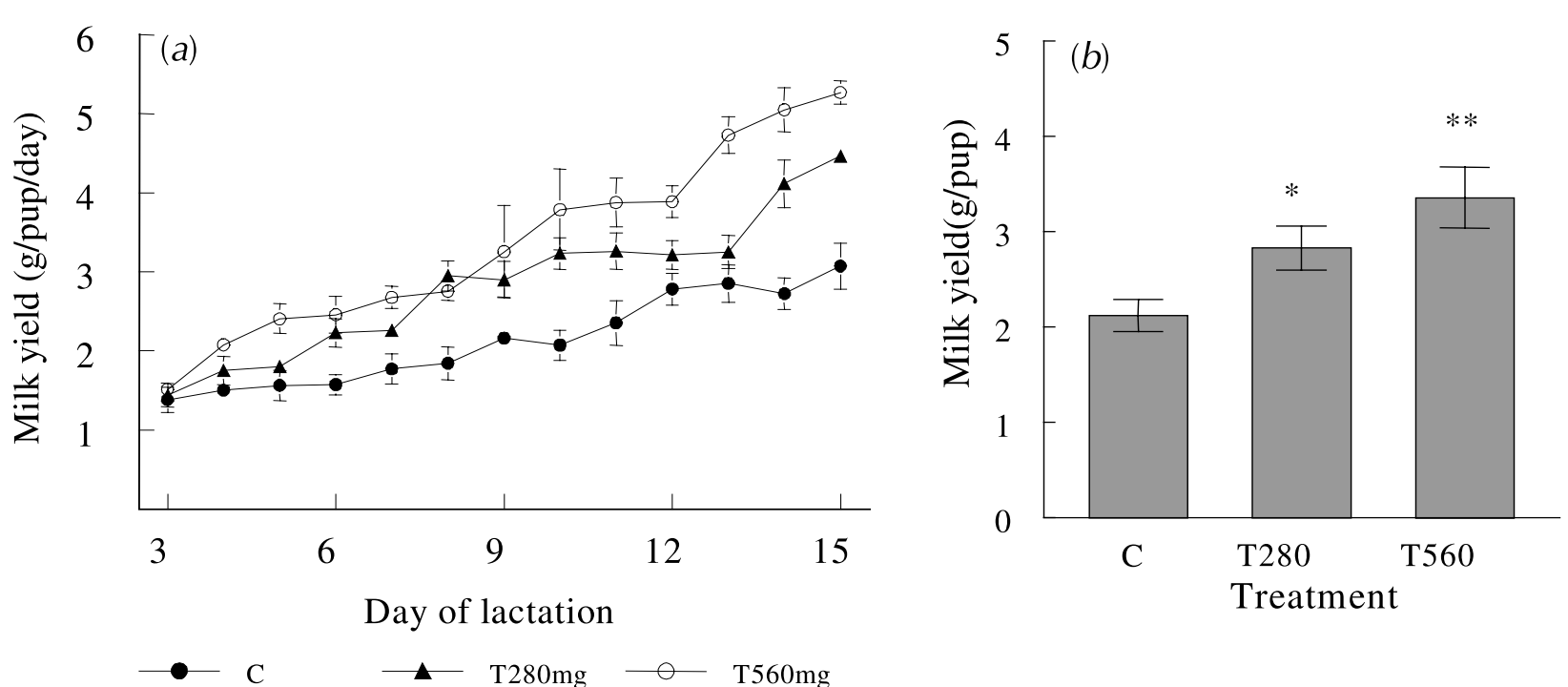

Figure 1 (a) Effect of aqueous extract of AN on milk production $18 \mathrm{~h}$ after gavage. Values are presented as means \pm S.E.M. A statistically significant difference was observed for the whole period for the group receiving $560 \mathrm{mg}(P<0 \cdot 01)$. In addition, a significant difference between days $8-11$ and days $14-15$ was observed for the group receiving $280 \mathrm{mg}(P<0 \cdot 05)$. Statistically significant differences are given compared to the control treatment (ANOVA followed by Bonferroni). (b) Mean milk production per day. Values are means \pm S.E.M. ${ }^{*} P<0.01 ;{ }^{*} P<0.05$ (Student's $t$-test with Bonferroni correction). C: control group treated with 0.9\% NaCl; T280 mg: group receiving $280 \mathrm{mg}$ of AN extract/kg body weight; T560 mg: group receiving $560 \mathrm{mg}$ of AN extract/kg body weight.

to $25 \cdot 20 \pm 1 \cdot 51 \mathrm{~g} /$ pup per day for those receiving $560 \mathrm{mg}$ extract. The daily weight gain was $0 \cdot 86 \pm 0 \cdot 08,1 \cdot 42 \pm$ $0 \cdot 12$ and $1 \cdot 43 \pm 0 \cdot 11 \mathrm{~g} /$ pup respectively (Fig. 3B). A significant difference was observed between all treated groups and the controls (Student's $t$-test with Bonferroni correction, $P<0 \cdot 01)$. No significant effect on the body weights of the dams was seen.

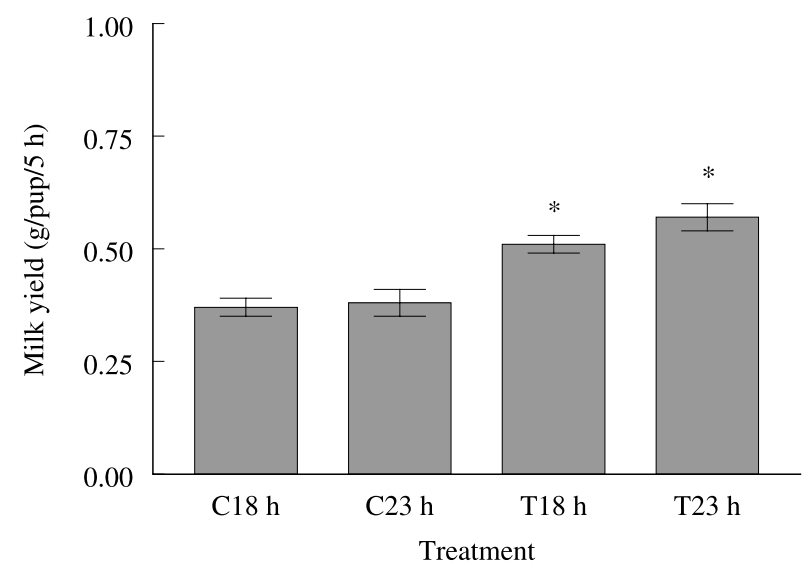

Figure 2 Mean milk production 18 and $23 \mathrm{~h}$ after gavage. Values are means \pm S.E.M. and have been given per $5 \mathrm{~h}$ (4-h separation plus 1-h suckling). C18 h: milk yield $18 \mathrm{~h}$ after gavage with saline $(n=7) ; \mathrm{T} 18 \mathrm{~h}$ : milk yield $18 \mathrm{~h}$ after gavage with AN extract ( $280 \mathrm{mg} / \mathrm{kg}$ body weight) $(n=8)$; C23 h: milk yield $23 \mathrm{~h}$ after gavage with saline $(n=7) ; \mathrm{T} 23 \mathrm{~h}$ : milk yield $23 \mathrm{~h}$ after gavage with AN extract $(280 \mathrm{mg} / \mathrm{kg}$ body weight) $(n=8)$. The Scheffe test was used to assess differences between groups. ${ }^{\star} P<0 \cdot 05$.

\section{PRL content}

To evaluate the effect of the extract on PRL secretion and release, PRL concentrations were measured in both plasma and the pituitary. In experiment II, the effect of an acute (Fig. 4A) and a 'chronic' (Fig. 4B) i.v. administration of the extract on the plasma PRL concentration was studied. A wide variation in individual responses to treatment was observed. However, the plasma PRL concentration was significantly higher in treated animals than controls; in the latter, the PRL level remained constant (non-parametric Kruskal-Wallis, at least $P<0 \cdot 05$ ). On day 1 of treatment (acute treatment), the highest levels were observed $1 \mathrm{~h}$ after the injection. They remained relatively high until day 3 ('chronic' treatment) of treatment, where the highest levels were observed earlier (40 min). PRL levels $40 \mathrm{~min}$ after the injection were $1.23 \pm 0.35,2.95 \pm 1.46$ and $56.03 \pm 22.84 \mathrm{ng} / \mathrm{ml}$ for controls, and the groups receiving 45 and $110 \mathrm{mg}$ on day 1 of the treatment respectively. On day 3 , the plasma levels were, at the same time, $4.02 \pm 0.76,10.53 \pm 2.44$ and $43.93 \pm 16.24 \mathrm{ng} / \mathrm{ml}$ for controls, and the groups receiving 45 and $110 \mathrm{mg}$ respectively. Furthermore, the pituitary PRL content for the same animals (Fig. 5) was significantly increased in the group receiving $110 \mathrm{mg}$ compared to the controls (ANOVA followed by Bonferroni, $P<0 \cdot 01$ ), although no significant increase was found for the group receiving the lower dose.

With regard to pituitary PRL in animals receiving the extract intramuscularly (experiment III), significantly higher PRL concentrations were observed in the 

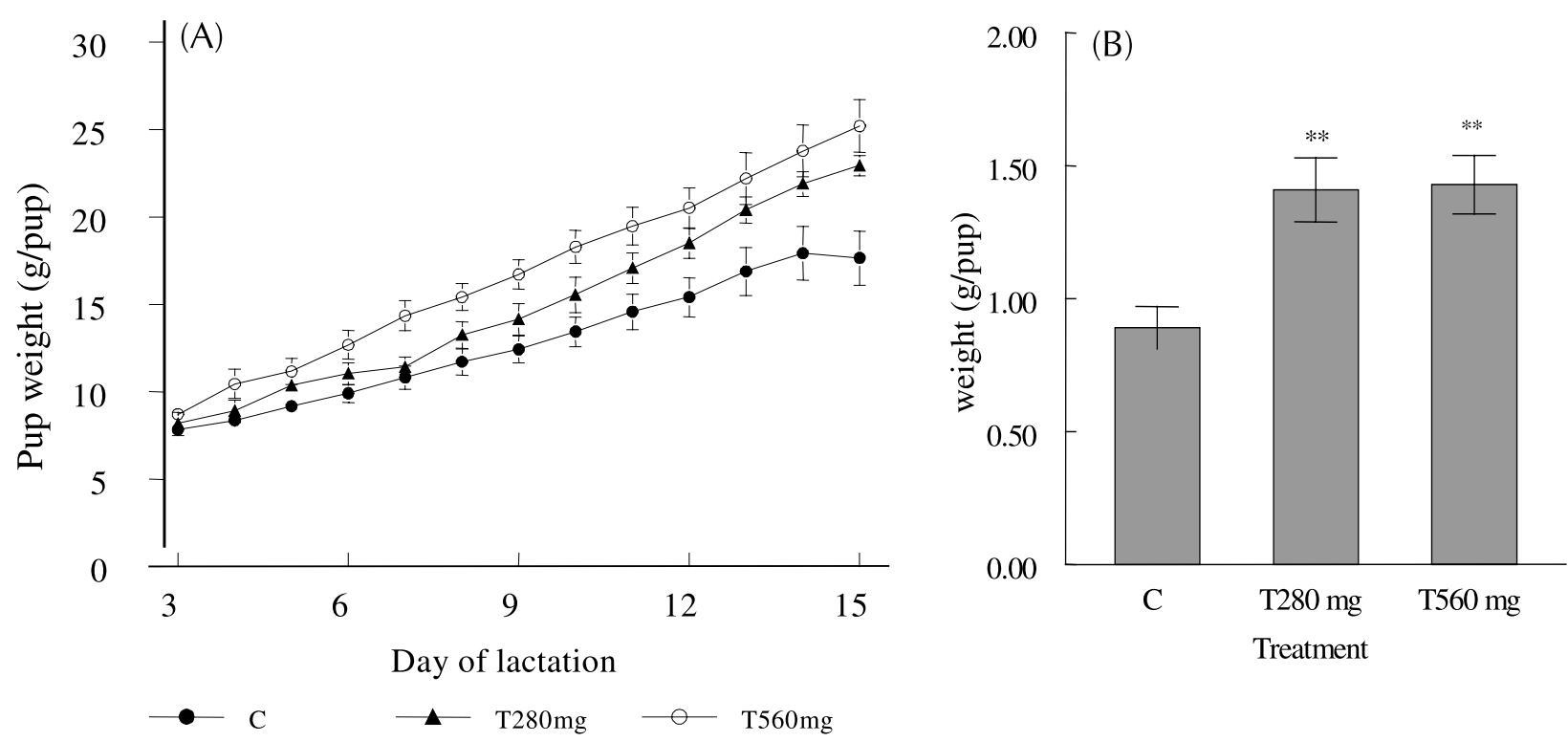

Figure 3 (A) Effect of aqueous extract of AN on pup weight after 18-h gavage. Values are means \pm S.E.M. A significant difference was observed between the treated group and the controls (at least $P<0 \cdot 05$ ). (B) Mean weight gain of pup. Values are means \pm S.E.M..

** indicates statistical significance $(P<0 \cdot 01)$ (Student's $t$-test followed by Bonferroni correction). C, T280 mg, and T560 mg: see Fig. 1 legend for explanation.

E2-primed animals treated with the extract than in the non-primed ones (ANOVA, followed by Bonferroni, at least $P<0 \cdot 05$ ) (Fig. 6). Moreover, a significant increase was found for the E2-primed animals receiving the extract compared to the E2-primed control group.

In both CB154-treated groups (Fig. 7), pituitary PRL content was significantly lower than the control value $(P<0 \cdot 05)$. AN treatment significantly increased PRL content compared to that in both animals treated with either CB154 alone or CB154 plus AN extract $(P<0 \cdot 05)$, albeit the treatment with the extract after CB154 injection had no effect on PRL content.

\section{Histology of mammary tissue}

To understand the relationship between PRL and mammary growth, the histology of rat mammary gland tissues was studied in the third experiment (Fig. 8). The mammary glands of non-E2-primed rats treated with saline showed a bare duct system and terminal end buds (TEBs) within an important fat pad (A). In the mammary gland of the E2-primed animals, ducts branching into ductule (B), with less alveolar bud (Alvbs) development, were observed. In all of E2-primed and non-primed animals receiving AN extract $(\mathrm{C}-\mathrm{F})$, ductule branching with alveolar development, and lipid droplets in the alveoli, was observed. However, there was no evidence of secretion in the ducts of the non-primed group receiving $400 \mathrm{mg}$ AN extract $/ \mathrm{kg}$ body weight (E). The largest alveolar structures with basophilic secretions in the lumen of alveoli and ducts were observed in the oestrogen-primed group receiving $400 \mathrm{mg}$ AN extract.

\section{Discussion}

The measurement of milk production rates in rats is difficult. Milk yield estimations for rats by means of pup weight and weight gains have been used in several studies (Morag et al. 1975, Sampson \& Jansen 1984, Kamani et al. 1987, Kim et al. 1998). It has to be noted that the purpose of this study was essentially to determine whether AN extract is lactogenic. As expected, milk production was significantly higher in the treated animals than in the controls. In addition, milk yield appears to be significantly stimulated about $24 \mathrm{~h}$ after administration of the extract and the pup growth rate was significantly improved. Moreover, the pup growth rate in the group receiving the lower dose (that is, T280, in the same range as that used by the native women) was similar to that in the group receiving the higher dose, whereas the dams produced $20 \%$ less milk. This suggests a possible effect of the extract on milk components. However, the suggestion can be confirmed only by studying the composition of the milk. Likewise, extract of Asparagus racemosus has been observed to stimulate milk production in buffaloes (Patel \& Kanitkar 1969). On the other hand, treatment with some of these plants did not improve the pup growth rate in rats (Kamani et al. 1987) or milk production in ewes (Sawadogo et al. 1989) but did stimulate PRL secretion in 

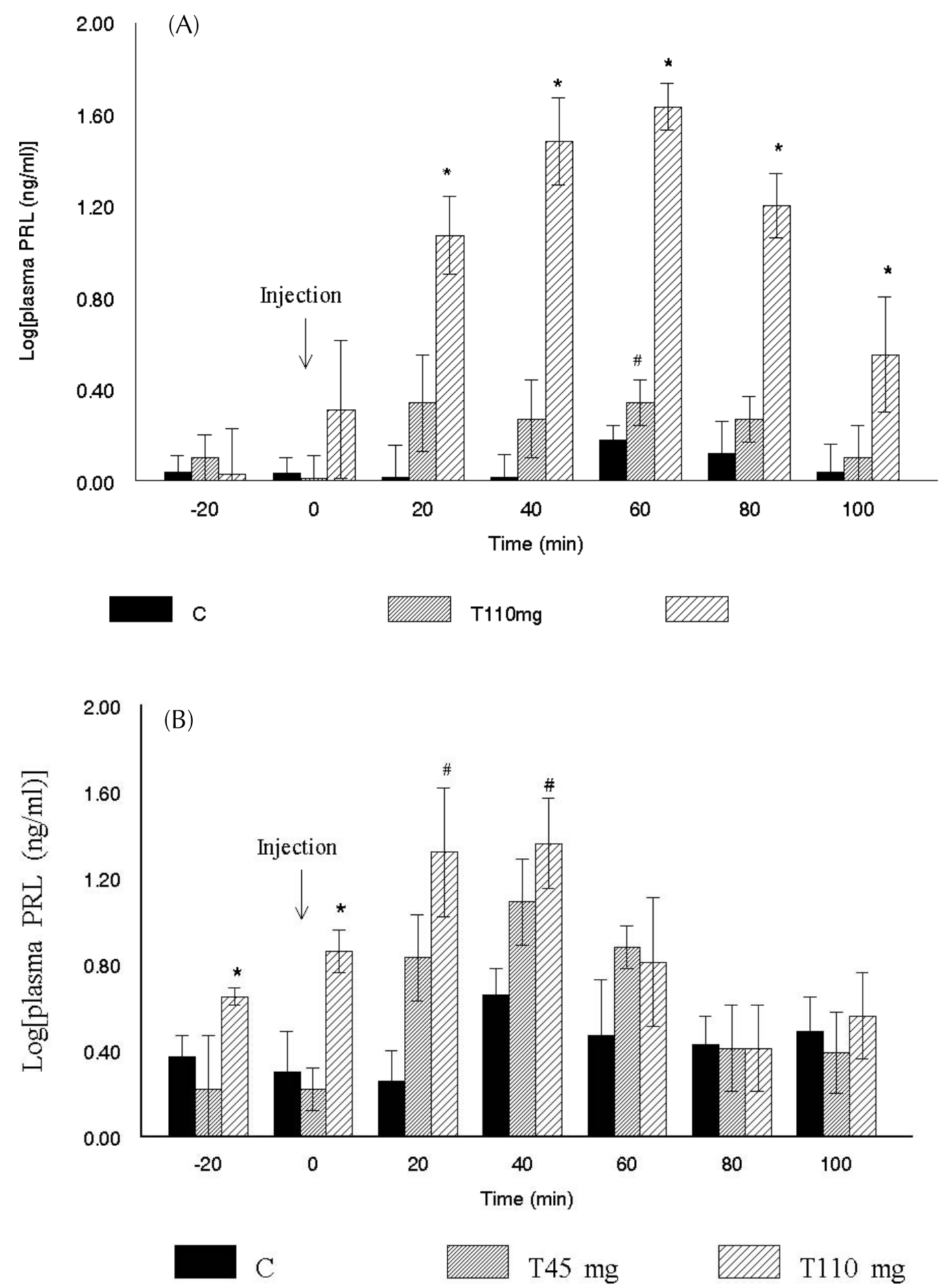

Figure 4 Plasma PRL profiles after acute (A) and 'chronic' (B) treatment (i.v. injection). Values are means \pm S.E.M. *Statistically significant compared to both controls and the group receiving $45 \mathrm{mg}$ (at least $P<0 \cdot 05$ ); \#statistically significant compared to the controls (at least $P<0 \cdot 05$ ) (ANOVA followed by Bonferroni). C: control treated with $0.9 \% \mathrm{NaCl}$ (i.v.); T45 mg: group receiving $45 \mathrm{mg}$ of $\mathrm{AN}$ extract/ $\mathrm{kg}$ body weight (i.v.); T110 mg: group receiving $110 \mathrm{mg}$ of AN extract/ $\mathrm{kg}$ body weight (i.v.). ' 0 ' time represents the time of injection of AN extract with samples taken at 20-min intervals after injection. 


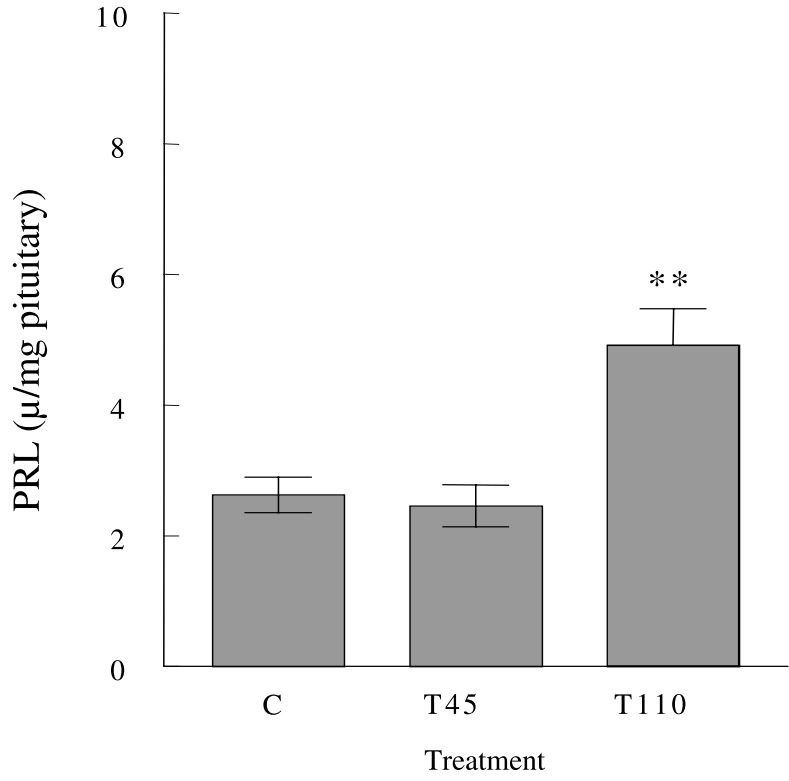

Figure 5 Pituitary PRL content after i.v. injection, treatment during 6 days. Values are means \pm S.E.M. ${ }^{* *}$ Statistically significant $(P<0 \cdot 01)$ (ANOVA followed by Bonferroni). C: control group receiving $0.9 \% \mathrm{NaCl}$ (i.v., 6 days); T45 mg: group receiving $45 \mathrm{mg}$ of AN extract/kg body weight (i.v., 6 days); T110 mg: group receiving $110 \mathrm{mg}$ of $\mathrm{AN}$ extract/ $\mathrm{kg}$ body weight (i.v., 6 days).

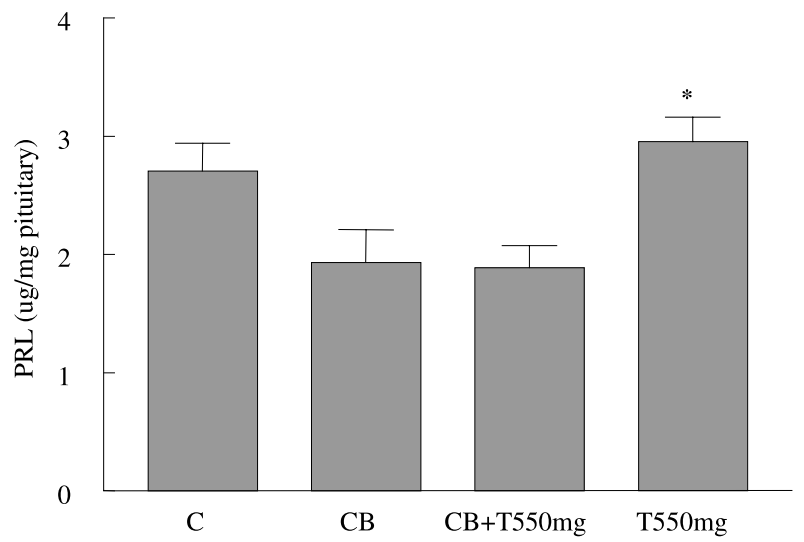

Figure 7 Pituitary PRL content after oral administration of the extract and after subcutaneous injection of CB154. Values are means \pm S.E.M. *Statistically significant compared to the bromocriptine-treated group receiving AN extract (ANOVA followed by $L S D, P<0 \cdot 05)$. C: control group receiving $0.9 \% \mathrm{NaCl}$ (oral, 5 days); CB: group receiving CB154 injection (subcutaneous, 5 days); $\mathrm{CB}+\mathrm{T} 550 \mathrm{mg}$ : group receiving CB154 injection (subcutaneous, 2 days) plus T550 mg (oral, 3 days); T550 mg: group receiving AN extract (oral, 5 days).

ewes (Sawadogo et al. 1989). Interestingly, the results obtained in this study showed not only that milk production was increased but also that plasma and pituitary PRL levels were increased. The mechanism of action is still unknown as are the active components in the

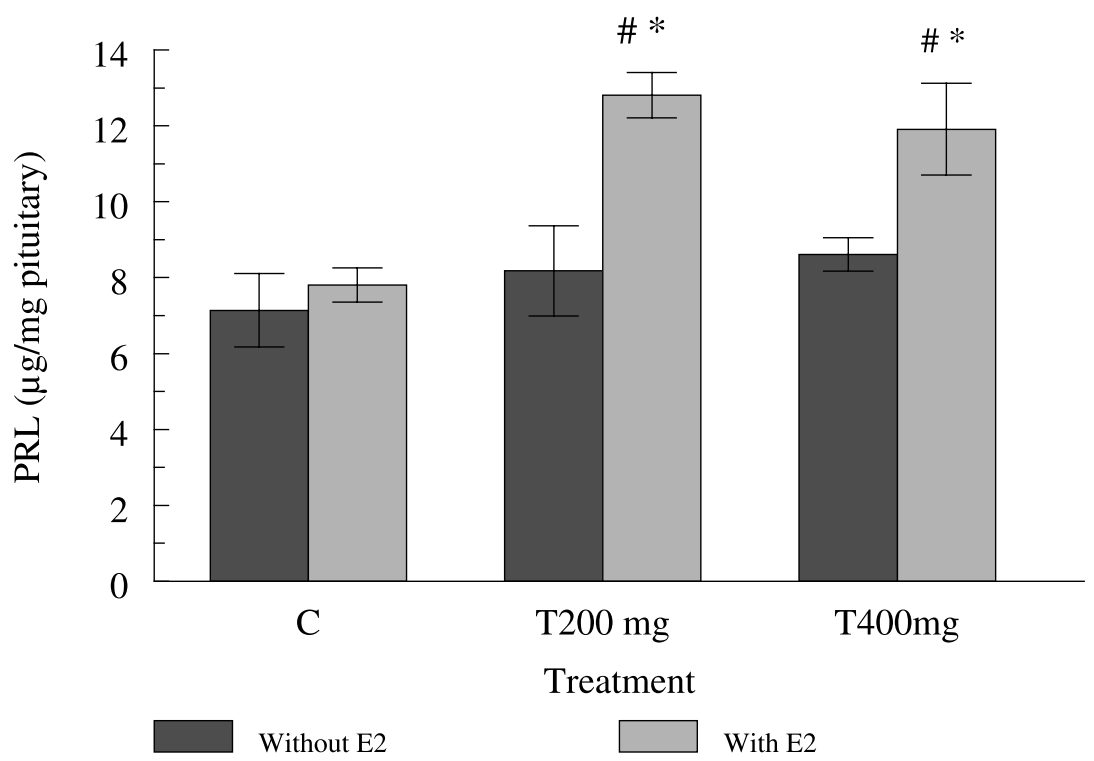

Figure 6 Pituitary PRL content after i.m. injection. Values are means \pm S.E.M. *Statistically significant compared to the control; \#statistically significant compared to the E2-primed control group. (ANOVA followed by Bonferroni, at least $P<0 \cdot 05$ ). Without E2: not previously treated with oestradiol; with E2: previously treated with oestradiol. C: control group receiving $0.9 \% \mathrm{NaCl}$ (i.m., 5 days); T200 mg: group receiving $200 \mathrm{mg}$ of $\mathrm{AN}$ extract $/ \mathrm{kg}$ body weight (i.m., 5 days); T400 mg: group receiving $400 \mathrm{mg}$ of AN extract/kg BW (i.m., 5 days). 

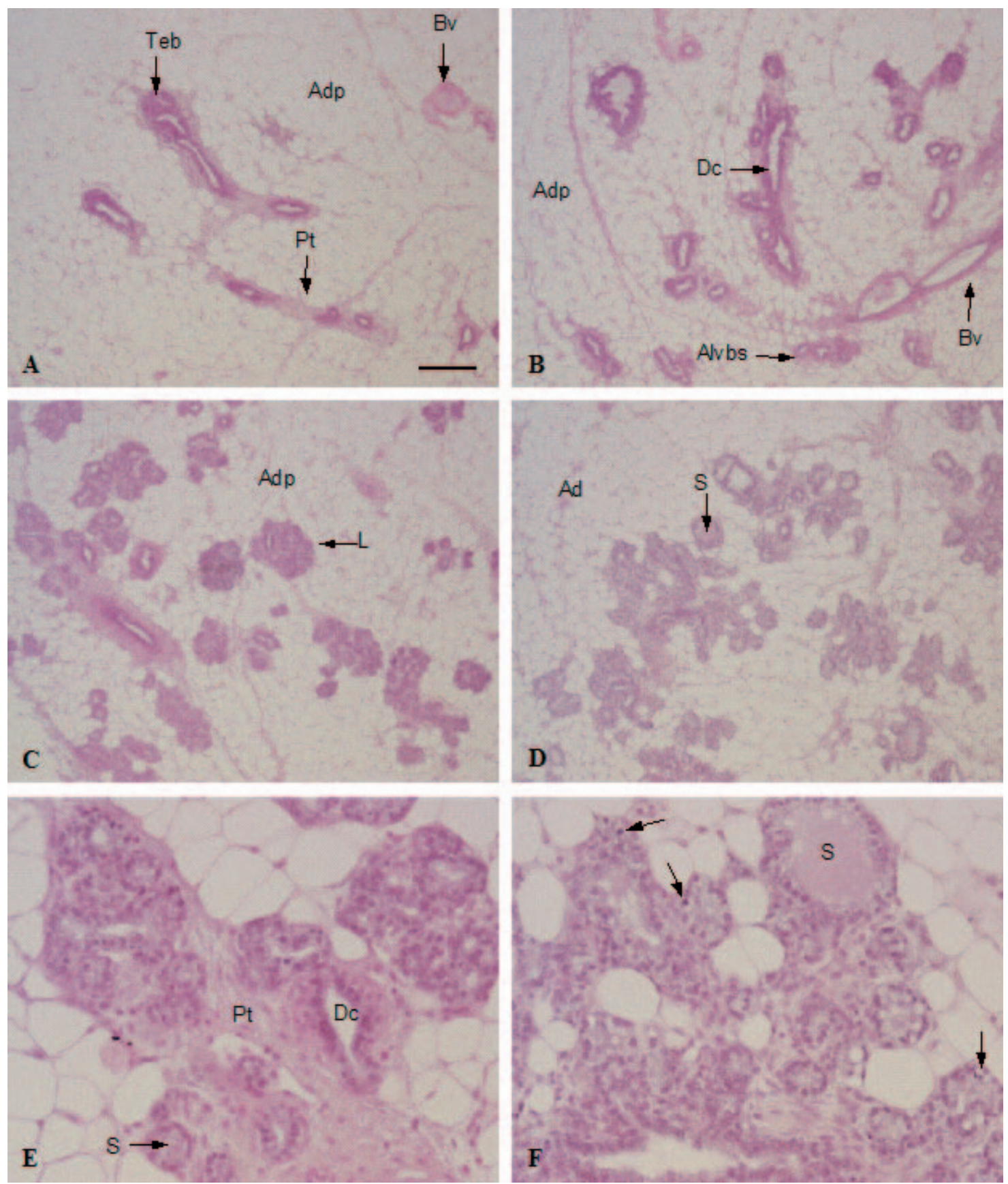

Figure 8 Sections of mammary glands from virgin oestrogen (E2) primed and non-primed rats 60-70 days old treated with saline or AN extract. (A) Mammary gland from a non-primed rat receiving $0.9 \% \mathrm{NaCl}$, showing ductules and terminal end buds, but no alveolar development. Notice the abundance of mammary fat pad. (B) Mammary gland from an oestrogen-primed rat receiving $0.9 \% \mathrm{NaCl}$, showing ducts branching into ductule, with fewer alveolar buds (Alvbs). (C) Mammary gland from a non-primed rat receiving $400 \mathrm{mg}$ AN extract/kg body weight, showing a well-defined alveolar structure (compare panels A and B) with fewer lipid droplets within the alveoli (compare panel D). (D) Mammary gland from an oestrogen-primed rat receiving $400 \mathrm{mg}$ AN extract/kg body weight, showing a well-defined alveolar structure with lumens filled with basophilic secretions (S) (see panel F) (compare panels A and B). Mitotic cells are also observed (panel E). Paraffin-wax sections of $5 \mu \mathrm{m}$ were stained with Harris' haematoxylin and eosin. Magnification: panels A-D $\times 100$; panels $\mathrm{E}$ and $\mathrm{F} \times 200$. Teb, terminal end bud; Adp, adipose tissue; Bv, blood vessel; L. lobule, Dc, ductus; Avbs, alveolar buds; S, basophilic secretion; Pt, proliferating tissue. 
extract. However, we suggest an effect through the hypothalamo-pituitary axis leading to the synthesis and release of PRL, as observed in previous studies (Sawadogo 1987, 1989, Sepehri et al. 1990, 1992). Moreover, the pituitary PRL content in the peripubertal animals treated just with the extract did not significantly differ from the control, compared to that in the cycling female treated intravenously with the extract. This indicates that the extract has a specific PRL-secretion activity under certain physiological conditions. A strong relation between treatment with the extract and PRL release after 'acute' as well as 'chronic' treatment has been observed. From this, it can be expected that the mechanism of the elevation of PRL will be related to neuroendocrine regulation. Our results may suggest involvement of dopaminergic activity, since the treatment with the extract after CB154 injection did not increase pituitary PRL content.

Obviously, PRL is known to stimulate milk synthesis and secretion, but in the last decades, research has also shown a relationship with breast carcinogenesis; the increase in PRL synthesis and release may increase susceptibility to carcinoma (Venugopal et al. 1999). In this study, extract of AN was shown to stimulate mammary gland development and the differentiation of the lobuloalveolar system from the lobular buds with milk secretion within the lumen. Immunohistochemical data on mammary cell proliferation must be obtained before any statement on the carcinogenic effect of the plant can be made. However, women have used this plant for generations without any pathological effects being reported. Further investigations are in progress and will provide more understanding of the effect of the extract on mammary gland development.

In conclusion, it can be stated that aqueous extract of AN effectively stimulates milk production as well as PRL synthesis and release in the rat. Therefore, the traditional belief that AN extract can improve milk production in lactating women may be valid.

\section{References}

Adjanohoun E, Ake AL, Florret JJ, Guinko S, Koumare M, Amyi AMR \& Raynal J 1979a Médecine traditionnelle et pharmacopée. Contribution aux études ethnobotaniques et floristiques au Mali. Ed. Agence de Coopération Culturelle et Technique, Paris.

Adjanohoun E, Amyi AMR, Ake AL, Dan DH, Delmas M, De Souza S, Garba M, Guinko S, Kayonga A, Raynal JL \& Saadou M $1979 b$ Médecine traditionnelle et pharmacopée. Contribution aux études ethnobotaniques et floristiques au Niger. Ed. Agence de Coopération Culturelle et Technique, Paris.

Akhtar MS \& Khan QM 1985 Studies on the effect of Acacia arabica fruits (kikar) and Caralluma edulis roots (Chung) on blood glucose levels in normal and alloxan-diabetic rabbits. Pakistan Journal of Agriculture and Science 22 252-259.

Amos S, Akah PA, Odukwe CJ, Gamaniel KS \& Wambede C 1999 The pharmacological effects of an aqueous extract from Acacia nilotica seeds. Phytotherapy Research 13 683-685.
Bognounou O, Ouedraogo OC \& Ouedraogo OG 1974 Contribution à l'inventaire des plantes médicinales africaines en pays Mossi (Région de Ouagadougou - Burkina Faso). Colloque du CAMES, Lomé, Togo.

Brisken C, Kaur S, Chavarria TE, Binart N, Sutherland RL, Weinberg RA, Kelly PA \& Ormandy CJ 1999 PRL controls mammary gland development via direct and indirect mechanisms. Developmental Biology 210 96-106.

Dafallah AA \& al-Mustapha Z 1996 Investigation of the anti-inflammatory activity of Acacia nilotica and Hibiscus sabdariffa. American Journal of Chinese Medicine 24 263-269.

Djiane J, Houdebine LM \& Kelly PA 1982 Correlation between prolactin-receptor interaction, down-regulation of receptors, and stimulation of casein and deoxyribonucleic acid biosynthesis in rabbit mammary gland explants. Endocrinology 110 791-795.

El-Tahir A, Satti GM \& Khalid SA 1999 Antiplasmodial activity of selected Sudanese medicinal plants with emphasis on Acacia nilotica. Phytotherapy Research 13 474-478.

Flint DJ, Tonner E, Beattie J \& Panton D 1992 Investigation of the mechanism of action of growth hormone in stimulating lactation in the rat. Journal of Endocrinology 134 377-383.

Gelani AH, Shaeen F, Zaman M, Janbaz KH, Shah BH \& Akhtar MS 1999 Studies on antihypertensive and antispasmodic activities of methanol extract of Acacia nilotica pods. Phytotherapy Research 13 665-669.

Hennighausen L, Robinson GW, Wagner KU \& Liu W 1997 PRL signaling in mammary gland development. Journal of Biological Chemistry 272 7567-7569.

Horseman ND 1999 Prolactin and mammary gland development. Journal of Mammary Gland Biology and Neoplasia 4 79-88.

Hussein G, Miyashiro H, Nakamura N, Hattori M, Kawahata T, Otake T, Kakiuchi N \& Shimotohno K 1999 Inhibitory effect of Sudanese plant extracts on HIV-1 replication and HIV-1 protease. Phytotherapy Research 13 31-36.

Hussein G, Miyashiro H, Nakamura N, Hattori M, Kakiuchi N \& Shimotohno K 2000 Inhibitory effect of Sudanese plant extracts on HIV-1 replication and HIV-1 protease. Phytotherapy Research 14 510-516.

Kamani HT, Karunanayake EH \& Mahindartna MPD 1987 Evaluation of galactoguic activity of Asparagus falcatus. Ceylon Journal of Medical Sciences 30 63-67.

Kim SH, Moon YS, Keller WL \& Park CS 1998 Compensatory nutrition-directed mammary cell proliferation and lactation in rats. British Journal of Nutrition 79 177-183.

Knight CH, Calvert DT \& Flint DJ 1986 Inhibitory effect of bromocriptine on mammary development and function in lactating mice. Journal of Endocrinology 110 263-270.

Llovera M, Touraine P, Kelly AP \& Goffin V 2000 Involvement of PRL in breast cancer: redefining the molecular targets. Experimental Gerontology 35 41-51.

Madon RJ, Ensor DM, Knight CH \& Flint DJ 1986 Effects of an antiserum to rat growth hormone on lactation in rat. Journal of Endocrinology 111 117-123.

Masso-Welch PA, Darcy KM, Stangle-Castor NC \& Ip MM 2000 A developmental atlas of rat mammary gland histology. Journal of Mammary Gland Biology and Neoplasia 5 165-185.

Morag M, Popliker F \& Yagil R 1975 Effect of litter size on milk yield in the rat. Laboratory Animals 9 43-47.

Nacoulma-Ouédraogo OG 1996 Plantes médicinales et pratiques traditionnelles au Burkina: cas du plateau central.Thèse de Doctorat Es Sciences Naturelles, Université de Ouagadougou, vol II, p. 285.

Patel AB \& Kanitkar UK 1969 Asparagus racemosus Willd form. bordi as a galactogogue in buffaloes. Indian Veterinary Journal 46 718-721.

Russo IH \& Russo J 1978 Developmental stage of rat mammary gland as determinant of its susceptibility to 7,12-dimethyl-benz [a] anthracene. Journal of National Cancer Institute 60 1451-1459.

Russo IH \& Russo J 1996 Mammary neoplasia in long-term rodent studies. Environmental Health Perspectives 104 938-967. 
Sabnis PB, Gatonde BB \& Jetmalani M 1969 Effects of Asparagus racemosus on mammary glands of rats. Indian Journal of Experimental Biology 6 55-56.

Sampson DA \& Jansen GR 1984 Measurement of milk yield in lactating rat from pup weight and weight gain. Journal of Pediatry, Gastroenterology and Nutrition 3 613-617.

Sawadogo L 1987 Contribution à l'étude des plantes médicinales et de la pharmacopée traditionnelle africaine. Thèse de Doctorat d'état, Université de Tours.

Sawadogo L \& Houdebine LM 1988 Induction de la synthèse de caséine- $B$ dans la glande mammaire de rates traitées par des extraits de plantes. Comptes Rendus de l'Academie Sciences Paris 306 167-172.

Sawadogo L, Houdebine LM, Thibault JF \& Rouau X 1988a Mise en évidence d'extraits de plantes possedant une activité galactogène. Bulletin Médecine Traditionelle 2 133-146.

Sawadogo L, Houdebine LM, Thibault JF, Rouau X \& OlivierBousquet M 1988b Effect of pectic substances on PRL and growth hormone secretion in the ewe and on the induction of casein synthesis in the rat. Reproduction, Nutrition, Development 28 293-301.

Sawadogo L, Sepehri H \& Houdebine LM 1989 Mise en évidence d'un facteur stimulant la sécrétion de PRL et d'hormone de croissance dans la drè che de brasserie. Reproduction, Nutrition, Development 29 139-146.

Sepehri H, Renard C \& Houdebine LM 1990 ß-Glucan and pectic derivatives stimulate PRL secretion from hypophysis in vitro.
Proceedings of the Society for Experimental Biology and Medicine 194 193-201.

Sepehri H, Kann G \& Houdebine LM 1992 Pouvoir lactogènes potentiel de quelques extraits de plantes iraniennes. Cahiers Agricultures $135-39$.

Shah BH, Safdar B, Virani SS, Nawaz Z \& Gilani AH 1997 The antiplatelet aggregatory activity of Acacia nilotica is due to blockage of calcium influx through membrane calcium channels. General Pharmacology 29 251-255.

Silberstein GB, Van-Horn K, Shyamala G \& Daniel CW 1994 Essential role of endogenous estrogen in directly stimulating mammary growth demonstrated by implants containing pure antiestrogens. Endocrinology 134 84-90.

Sotohy SA, Sayed AN \& Ahmed MM 1997 Effect of tannin-rich plant Acacia nilotica on some nutritional and bacteriological paramaters in goats. Deutsche Tierärztliche Wochenschrift 104 432-435.

Van Dongen JJ, Remie R, Rensema JW \& Van Wunnik GHJ 1990 Manual of Microsurgery on the Laboratory Rat. Amsterdam: Elsevier.

Venugopal M, Callaway A \& Snyderwine EG 1999 2-Amino-1-methyl-6-phenylimidazo [4,5-b] pyridine (PhIP) retards mammary gland involution in lactating Sprague-Dawley rats. Carcinogenesis 20 1309-1314.

Received in final form 24 March 2004

Accepted 14 May 2004 